\title{
In Vitro Assessment of the Antimicrobial Efficacy of Chitosan from Scylla serrata Against the Human Pathogens
}

\author{
Sangeetha B.*, Indra V., Abdul Rahim M. and Venkadachalam E. \\ Department of Zoology, Presidency College, Chennai 600005, India \\ ${ }^{*}$ Corresponding Author
}

Received: $12^{\text {th }}$ April, 2021

Accepted: $10^{\text {th }}$ May, 2021

Published online: $12^{\text {th }}$ May, 2021

https://doi.org/10.33745/ijzi.2021.v07i01.016

\begin{abstract}
Chitosan, a polysaccharide derivative of chitin forms the structural components in the exoskeletons of crustacean animals and is also found in the cell walls of fungi. Chitosan is produced primarily from the crab shell waste through chemical means. The chemical structure of chitosan has been identified and characterized by FT-IR and XRD. In the current study, the antimicrobial activity of chemically deacetylated chitosan extracts of mud crabs (Scylla serrata) was evaluated against five human pathogenic isolates viz. Staphylococcus aureus, Salmonella typhi, Klebsiella pneumonia, Bacillus cereus and Pseudomonas aeruginosa using agar disc diffusion method. These were performed to determine the crystallinity and functional properties of chitosan. The results showed that the antibacterial effect increased with increasing chitosan concentration. This study showed that chitosan isolated from crab shell has potential antibacterial activity therefore it can be utilized in the food and pharmaceutical industries, and that antibacterial activity may be due to functional groups present in the crab shell.
\end{abstract}

Keywords: Chitosan, XRD, FI-IR, Antibacterial activity, Micro-organisms, Scylla serrata

Citation: Sangeetha B., Indra V., Abdul Rahim M. and Venkadachalam E.: In vitro assessment of the antimicrobial efficacy of chitosan from Scylla serrata against the human pathogens. Intern. J. Zool. Invest. 7 (1): 193-200, 2021. https://doi.org/10.33745/ijzi.2021.v07i01.016

\section{Introduction}

The Scylla serrata (Indian mud crab) is a commercially important species. Mud crab farming is actively practiced in the Asian countries such as Bangladesh, China,
Indonesia, Malaysia, Singapore, Taiwan, Philippines and Vietnam. In India, mud crab is farmed in various parts of the country including West Bengal, Orissa, Andhra 
Pradesh, Tamilnadu, Kerala, Karnataka, Goa, Maharashtra and Andaman Islands (Poornima et al., 2012). Annually, around 6 to 8 megatonnes of crab, shrimp and lobster shells are produced as waste around the world and southeast Asian countries alone accounted for about 1.5 megatonnes of shell powder used for animal feed supplement, fertilizer and chitin production used (Yan and Chen, 2015). Chitosan is a type of polysaccharide that has a exclusive nature of resourceful physicochemical which possess biological properties that allows for a variety of combinations. The vital biological property of chitosan is antimicrobial activity because of its bacteriocidal or bacteriostatic property. Chitosan is a positively charged molecule and interact with the negative charged cell wall and inhibit the cell growth (Goy et al., 2009). Due to its antibacterial properties, it can be widely used as a food preservative of innate source (Sanford, 1989). In the food packaging process, microbial contamination, microbial growth and lipid oxidation of food determines the shelf life of the packaged food. Similarly most of the food borne disease due to the consumption of packaged food is due to the growth of microorganism. Therefore, regulators have approved a significant number of antimicrobial and antioxidants to lessen the deprivation of packaged foods. Using synthetic preservatives in the food packaging process causes adverse toxic effects (Roller, 2001).

Chitosan is a polymer and the most impotant physical properties that help to evaluate the polymer functional property are the molecular weight and the crystallinity (Trung et al., 2006). The unacetylated chitin and fully deacetylated chitosan show the maximum crystallinity property. During the mass production, the outer shell of the crustaceans is used to manufacture a chitin and chitosan (Liu et al., 2006). Chitosan have the ability to form water soluble salts along with inorganic and organic acids namely glutamic acid, hydrochloric acid, lactic acid, and acetic acid. Moreover, this compound is not soluble at neutral and alkaline $\mathrm{pH}$ but in the acidic medium it dissolves and the amino groups is protonated and it becomes positively charged. The rate of acetylation property is based on the fraction of $\mathrm{N}$-acetylD-glucosamine units present in the total number of units (Van et al., 2013). Because of the versatile property of Chitosan, this polymer has various applications in different areas like waste water treatment, agriculture, textiles, cosmetics, nutritional improvement and food processing. Allergenicity, biocompatibility, biodegradability and bioactivity of this polymer make it as a very potent substance for diverse applications as biomaterial in the biomedical, food and chemical industries. This study elucidates the antimicrobial activity of the chitosan against some human pathogenic isolates.

\section{Materials and Methods}

Sample Collection:

Healthy Scylla serrata (Indian mud crab) approximately weighing $100 \mathrm{~g}$ were sourced from local suppliers in and around Chennai, India. The collected mud crab were adapted and sustain in the lab facility at Presidency College, PG department of Zoology, Chennai, Tamil Nadu, India. The animals were nurtured in a germ free clean $100 \mathrm{~L}$ plastic tanks provided with good ventilation (Salinity $28 \pm 2$ ppt; temperature $30 \pm 2 \mathrm{C}$ ). The frozen shrimp muscle was given to crabs for nourishment for two times maintained in a 
healthy condition for 10 days. Prior to experimentation, the crabs were cleaned, surface sterilized and dissected aseptically as described by Sivakumar et al. (2019). The intact cephalothorax and abdominal exoskeleton were collected from selected mud crab. The collected shells were washed thoroughly with sterile seawater and stored at $20 \mathrm{C}$. The shells were dehydrated in a hot-air oven at $90 \mathrm{C}$ for $6 \mathrm{~h}$ for removing the water and impurities. Shells were well homogenized using a blender into a fine powder. The homogenized material was preserved at $4 \mathrm{C}$ for further use.

Molecular authentication of Scylla serrata:

The genomic DNA was isolated from the gill of mud carb and PCR was done as described by Sivakumar et al. (2019). The Cytochrome c Oxidase subunit I (COI) genes were amplified using universal primers $F 5^{\prime}$ - TCA ACC AAC CAC AAA GAC ATT GG CAC-3' and R 5'- TAG ACT TCT GGG TGG CCA AAG AAT CA-3'. The reaction mixture contains $25 \mu \mathrm{l}$ which has both forward and reverse primers $(25 \mathrm{ng} / \mu \mathrm{l}$ each), $0.1 \mu$ template, Master mix and nuclease free water $(18.0 \mu \mathrm{l})$. The condition for PCR was as follows: Initial denaturation at $95 \mathrm{C}$ for $5 \mathrm{~min}$ followed by 35 cycles of denaturation at $95 \mathrm{C}$ for $30 \mathrm{sec}$, annealing at $47 \mathrm{C}$ for $30 \mathrm{sec}$, extension at $72 \mathrm{C}$ for $1 \mathrm{~min}$ and final extension at $72 \mathrm{C}$ for $10 \mathrm{~min}$. The PCR products were visualized on $2.0 \%$ agarose gels purified and sequenced using an automated DNA sequencer at Eurofins Genomics, India. With the help of the bioinformatics tool Basic Local Alignment Search Tool (BLAST) and National Center for Biotechnology database (NCBI), the gene sequences were compared. The sequence was submitted in NCBI GenBank.
Isolation of chitosan from mud crab shell:

The chitosan extraction protocol consists of the following steps-- (1) Crab shell powder $(20 \mathrm{~g})$ was demineralized with $100 \mathrm{ml}$ of $7 \%$ $\mathrm{HCl}$ for $30 \mathrm{~min}$, with steady stirring and then filtered. The filtrate was continuously washed with distilled water till the liquid reaches neutral $\mathrm{pH}$, (2) This demineralized sample was again deproteinized with $250 \mathrm{ml}$ of $5 \%$ $\mathrm{NaOH}$ at $70 \mathrm{C}$ for $30 \mathrm{~min}$ with continuous stirring. Again the sample was rinsed with distilled water and filtered. Sample was Dried the and weight was noted, (3) The sample was deacetylated with $250 \mathrm{ml}$ of $40 \% \mathrm{NaOH}$ and treated for $3 \mathrm{~h}$ at $80 \mathrm{C}$ with constant stirring. Then sample was washed by deionized water till the liquid content showed neutral $\mathrm{pH}$ and then the sample was dried, (4) Stock solution of chitosan $(1.0 \mathrm{mg})$ was prepared in $2 \mathrm{ml}$ of $1.0 \%(\mathrm{w} / \mathrm{v})$ aqueous acetic acid solution. From this $0.50,0.75$ and $1.0 \mathrm{ml}$ was taken and made up $1.0 \mathrm{ml}$ by adding $1 \%$ acetic acid to prepare various concentrations of chitosan sample corresponding to 50,75 and $100 \%$, respectively.

\section{Characterization of chitosan:}

The functional groups present in the extracted chitosan were characterized by FT-IR (Bruker, 1000-3500 Cm-1). The wide-angle X-ray diffraction analysis was applied to detect the chitins crystallinity and chitosan prepared and their patterns were recorded using a Rigaku III diffractometer with $\mathrm{Cu}$ radiation (40 kV, $30 \mathrm{~mA}$ ).

Anti-microbial activity:

To study the anti-microbial activity, five different strains of micro-organisms were chosen including Salmonella typhi, Staphylococcus aureus, Klebsiella pneumoniae, 
Bacillus cereus and Pseudomonas aeruginosa. These were isolated from clinical samples. The micro-organisms were cultured on nutrient agar plate and incubated at $37 \mathrm{C}$ for $24 \mathrm{~h}$. The culture plates were then stored at $4 \mathrm{C}$ until use. Then, bacterial suspensions based on standard $\left(1.5 \times 10^{7} \mathrm{CFU} / \mathrm{ml}\right)$ were prepared. In vitro antibacterial activity of different concentration of chitosan $(10 \mathrm{mg}, 20 \mathrm{mg}, 30$ $\mathrm{mg}$ and $40 \mathrm{mg} / \mathrm{ml}$ ) was evaluated against five human pathogenic isolates using the agar well diffusion method. Stock cultures were inoculated in nutrient broth on the day before experiment and incubated for $12 \mathrm{~h}$ at $37 \mathrm{C}$. The five different organisms (each microorganism separately) were swabbed on the Muller-Hinton agar plates. Amikacin antibiotic disc (HiMedia, India) was used as the positive control.

\section{Results and Discussion}

Natural products are frequently used in formulation medicines in the treatment of various infections for several centuries. Currently it is also used for the commercial products including cosmetics, dietary supplements, pharmaceutical and food produced in replacement of artificial ingredient. In both the traditional and natural medicine, natural products were the active components which are mainly due to the presence of secondary metabolites which are used in the fields of medicine (Khaleel, 2018). Among the natural resources, crustaceans are widely used as a food ingredient. The generation of crab shell as a waste material is high and it can be converted as a good source for bioactive components (Karimzadeh and Pormehr, 2017). Therefore, in the present study chitosan was extracted and characterized from crab shell and it is studied for antimicrobial activity against the clinical strains.

IR Spectrum:

Chitosan IR spectrum results showed the distinctive absorption bands at $921.6 \mathrm{~cm}^{-1}$, $1180 \mathrm{~cm}^{-1}, 1603 \mathrm{~cm}^{-1}$ and $2999 \mathrm{~cm}^{-1}$ corresponding to the vibrations of surface hydroxyl group $(-\mathrm{OH})$ and can also be attributed to $\mathrm{N}-\mathrm{H}$ stretching of the $\mathrm{C}-\mathrm{OH}$ stretch (strong) and $-\mathrm{C}-\mathrm{H}$ aldehydic (variable) in extracted chitosan (Fig. 1).

$X$-ray Powder Diffraction (XRD):

The XRD was carried out to confirm its crystallinity and structural phase analysis. The diffraction pattern with the wavelength of the light source at CuK-Alpha: $(\lambda=0.154056$ Angstrom) is shown in Figure 2. The ratio of intensity between the planes confirms the preferred orientation of the particles in (111) plane characteristic of fcc crystalline structure. In addition to these reflection peaks, a number of unassigned peaks were observed which can be attributed to the presence of crystalline ratio.

\section{Molecular identification of COI region:}

PCR sequences obtained in this study were compared with the known sequences using the NCBI database. Analysis of mitochondrial COI was performed to verify the species of crab (Fig. 3). The sequences were submitted to GenBank with Accession number MW303435. The sequences showed 99\% similarity to COI region of Scylla serrata. The phylogenetic tree was created using mega 6 software (Fig. 4).

In vitro antibacterial activity test:

Results of the antibacterial assay showed that chitosan has a noteworthy result on the 


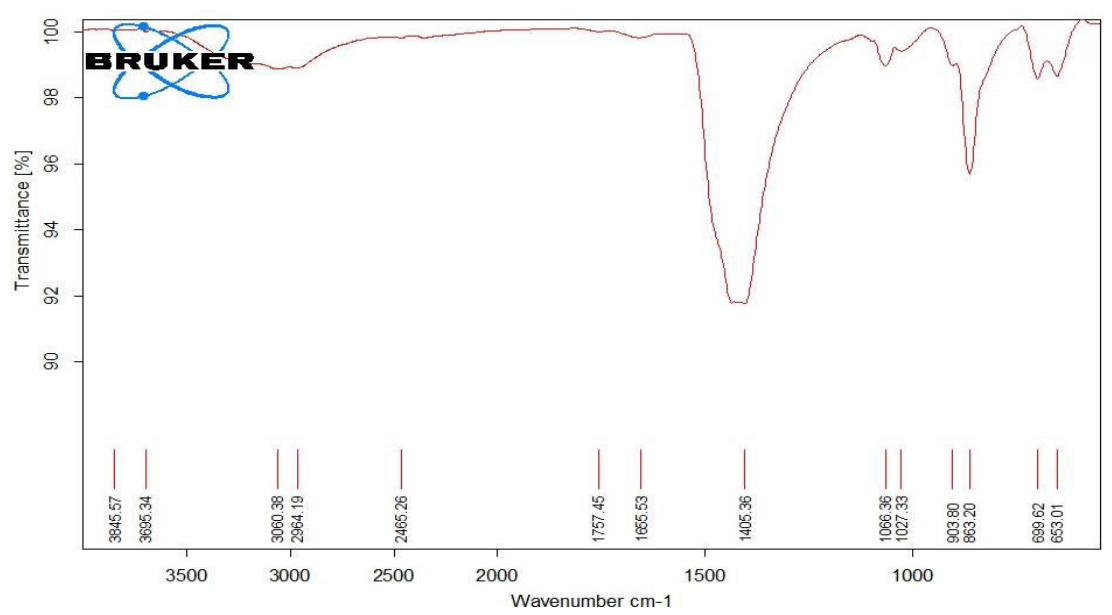

Fig. 1: IR spectra of chitosan

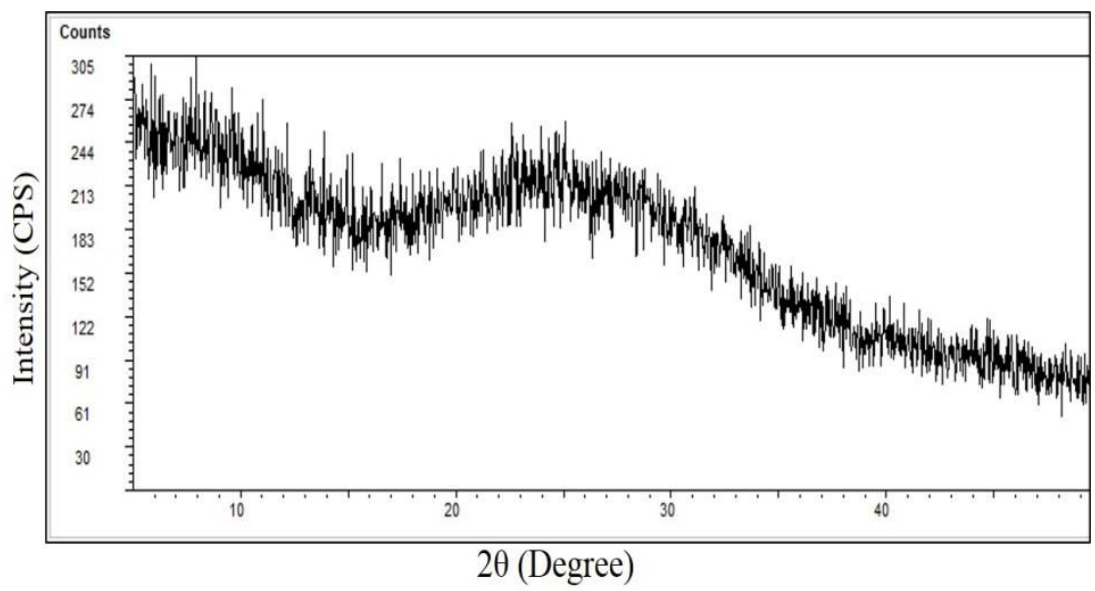

Fig.2: XRD spectra of chitosan

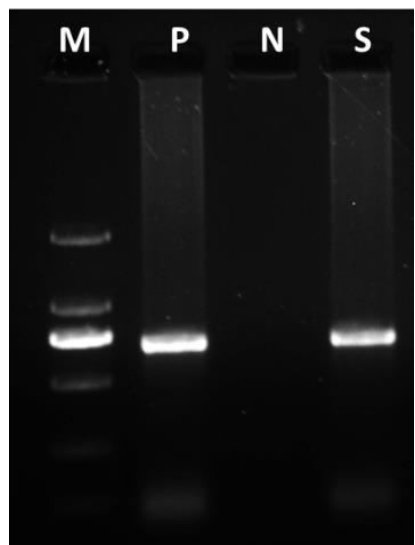

Fig. 3: Agarose gel electrophoresis of amplified PCR product. COI gene was confirmed by conventional PCR in mud crab Gill sample. M-Marker, P -Positive control, N-Negative control and S-Sample (Mud crab gill). 


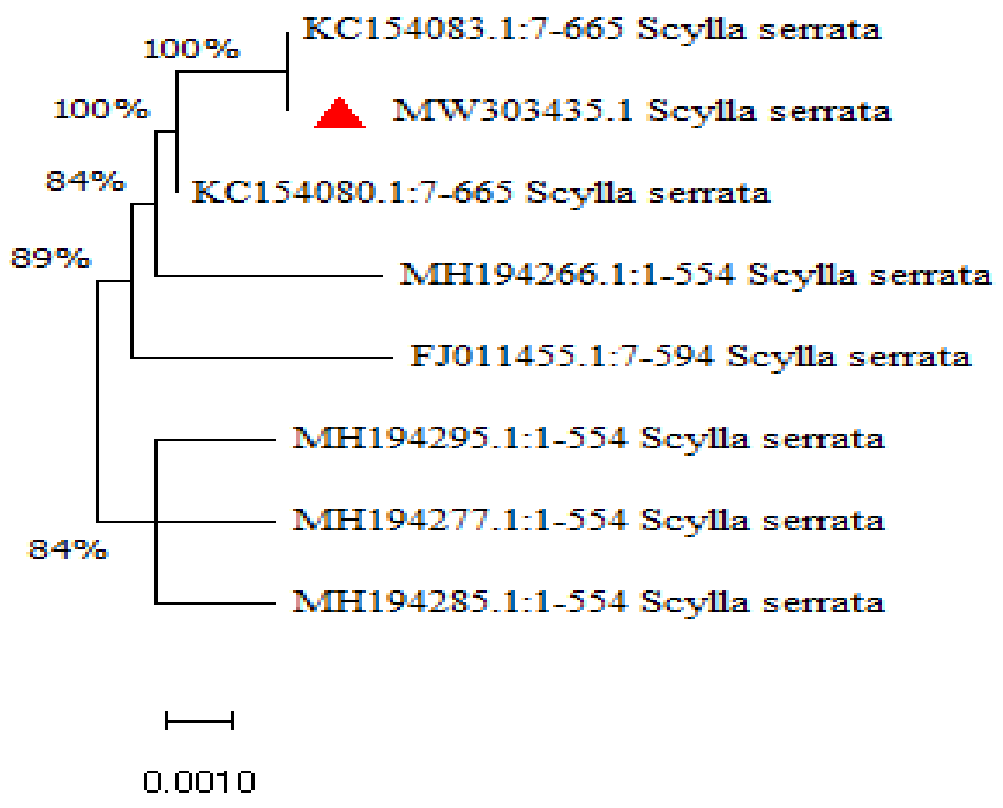

Fig. 4: The phylogenetic tree was generated by using the neighbor-joining (NJ) and minimum-evolution (ME) method using mega 6 software.

Table 1: Antibacterial activity of chitosan treated with clinical isolates

\begin{tabular}{|c|c|c|c|c|c|c|}
\hline S. No & Name of the organisms & \multicolumn{5}{|c|}{ Zone of inhibition in mm } \\
\hline & & \multicolumn{2}{|c|}{ Ak $20 \mu \mathrm{g}$} & $40 \mu \mathrm{g}$ & $60 \mu \mathrm{g}$ & $80 \mu \mathrm{g} / \mathrm{ml}$ \\
\hline 1 & S. aureus & 20 & 9 & 13.5 & 19 & 21 \\
\hline 2 & S. typhi & 13 & - & - & 9 & 14 \\
\hline 3 & K. pneumonia & 22 & - & 13 & 18 & 19 \\
\hline 4 & B. cereus & 12 & - & 7 & 10 & 14 \\
\hline 5 & P. aeruginosa & 21 & - & 9 & 14 & 20 \\
\hline
\end{tabular}

survival of Gram-positive and Gram-negative bacteria (Table 1). This effect may be due to the deacetylation levels which might enhance the antibacterial activity. Maximum zone of inhibition (21 $\mathrm{mm}$ ) was observed against $S$. aureus, $S$. typhi and B. cereus with the increase in concentration of $80 \mathrm{ug} / \mathrm{ml}$ when compared to other bacterial species and moderate zone 


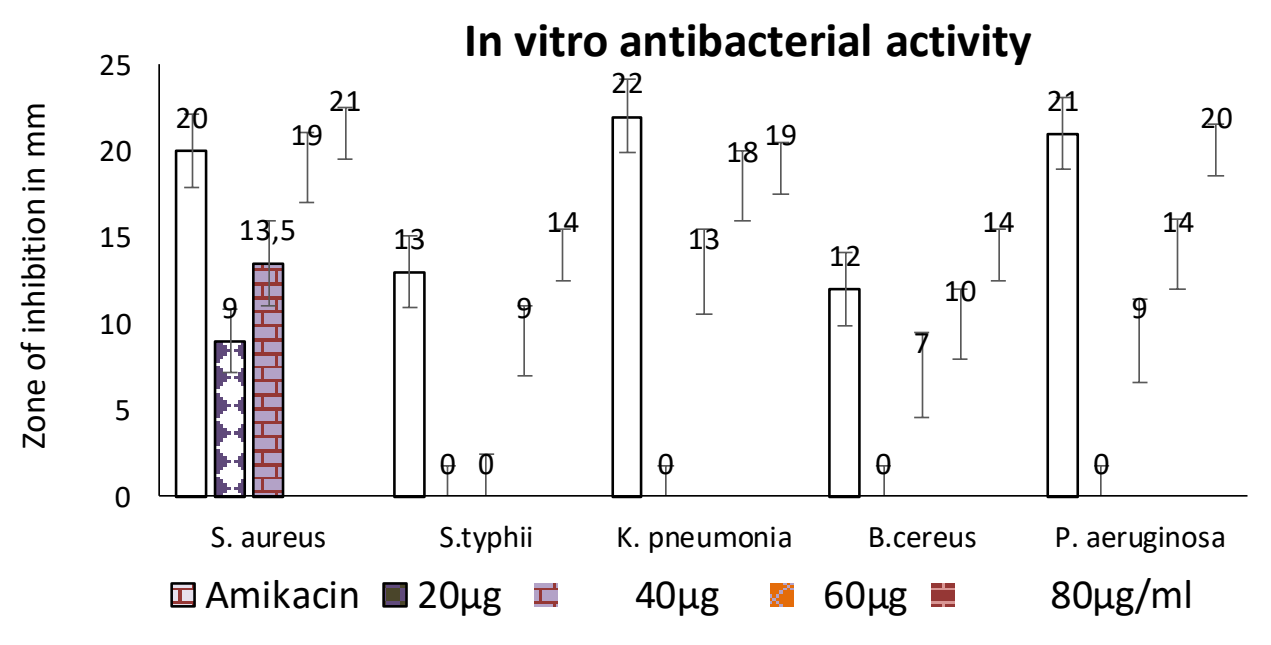

Fig. 5: Zone inhibition of bacteria treated with Chitosan at different concentration

of inhibition was observed in P. aeruginosa and $K$. pneumonia (Fig. 5). On the other hand, amikacin (Ak) alone showed higher activity in all the bacterial strain this may be due to its antibiotic nature of the drug.

Previous study by Raafat et al. (2008) showed that chitosan bind with the cell membrane and the cell membrane was detached from the cell wall which help in the formation of vacuole like structure underneath the wall lead to the decrease in the internal bacterial pressure thus cell death will occur. This mechanism was observed in both gram- positive and gram-negative bacteria

The results are presented in Figure 1 and Table 1. Antimicrobial activity of the Chitosan may be due to the release of potassium ions from the intracellular medium. Moreover, the antimicrobial effect is related to the chitosan concentration, illustrated by the zone of inhibition in relation to the chitosan concentration. Finally, the plot (Fig. 2) of the correlation between the various concentration of chitosan and zone of inhibition produced by the bacteria indicate that this may be due to the chitosan intervention which disrupts the barrier properties of the outer membrane of bacteria.

\section{Conclusion}

This study showed that chitosan powder has a high antibacterial activity. The antibacterial activity of the chitosan for $S$. aureus, $S$. typhi and B. cereus was higher when compared to $P$. aeruginosa and $K$. pneumoniae. The antibacterial activity of the Chitosan was dosedependent and this compound can be used as a promising antibacterial agent that could be useful in the pharmaceutical, food, water treatment and waste water reuse.

\section{Acknowledgement}

The authors wish to acknowledge the Head, Department of Zoology, The Presidency College, Chennai, India for the support throughout the study.

\section{References}

Goy RC, Britto DD and Assis OB. (2009) A review of the antimicrobial activity of chitosan. Polímeros 19: 241-247. 
Karimzadeh K and Pormehr M. (2017) Antibacterial activity of different extracts of prawn shell (Macrobrachium nipponense) against human bacterial pathogens. Int Arch Hlth Sci. 4: 13-16.

Khaleel F.D. (2018) Natural products and its scope and applications. GRIN Verlag.

Liu Nan'Xi-Guang Chen, Hyun-JinPark, Chen-GuangLiu, Cheng-ShengLiu, Xiang-Hong Meng and Le-JunY. (2006) Effect of MW and concentration of chitosan on antibacterial activity of Escherichia coli. Carbohydrate Polymers 64: 60-65.

Poornima M, Singaravel R, Rajan JJS, Sivakumar S, Ramakrishnan S, Alavandi SV and Kalaimani N. (2012) Vibrio harveyi infection in mud crabs (Scylla tranquebarica) infected with white spot syndrome virus. Int J Res Biol Sci. 2: 1-5.

Raafat D, Von Bargen K, Haas A and Sahl HG. (2008) Insights into the mode of action of chitosan as an antibacterial compound. Appl Environ Microbiol. 74: 3764-3773.

Roller S. (2001) Chitosan disrupts the barrier properties of the outer membrane of Gram-negative bacteria. Int J Food Microbiol. 71: 235-244.
Sanford PA. (1989) Chitosan: commercial uses and potential applications. In: Chitin and ChitosanSources, Chemistry, Biochemistry, Physical Properties and Applications. (eds.) Skjak-Braek G, Anthonsen T and Sanford S, Elsevier London, pp. 51-70.

Sivakumar S, Swaminathan RT, Kumar, R and Kalaimani N. (2019) The development and characterization of a cell culture system from Indian mud crabs Scylla serrata. J Aquat Anim Hlth. 31: pp.244-258.

Trung TS, Thein-Han WW, Qui NT, Ng CH and Stevens WF. (2006) Functional characteristics of shrimp chitosan and its membranes as affected by the degree of deacetylation. Bioresource Technol. 97: 659-663.

Van Toan T, Tran TH and Pham Vo Minh T. (2013) Antibacterial activity of chitosan on some common food contaminating microbes. The Open Biomaterials J. 4: 1-5.

Yan N and Chen X. (2015) Sustainability: Don't waste seafood waste. Nature 524:155-157. 